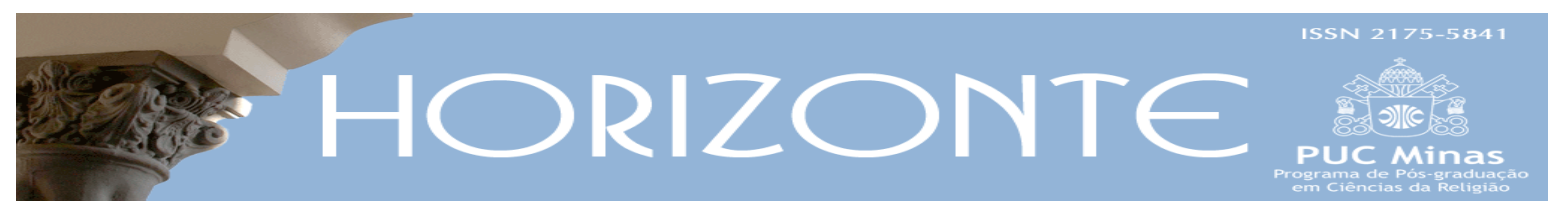

Dossiê: Religião e Educação - Artigo original ๑。

\title{
Entre a Igreja e a escola: \\ o catolicismo e a escola do campo no Marajó em conexão
}

\author{
Between Church and School: \\ Catholicism and field school in Marajó in connection
}

Eliane Miranda Costa*

\begin{abstract}
Resumo
O texto aborda a relação da educação escolar e o catolicismo no espaço rural - especialmente no rio Mapuá, no município de Breves, arquipélago de Marajó, estado do Pará. Tem-se por objetivo identificar a presença do catolicismo na escola do campo e a relação com a formação dos alunos ribeirinhos. Especificamente, a perspectiva é discutir a influência dos rituais religiosos e artefatos sagrados no processo educativo e na cultura escolar do campo. É uma investigação de natureza qualitativa, fundamentada na incursão bibliográfica e pesquisa de campo, cujos dados empíricos foram coletados por meio de observações etnográficas, entrevistas semiestruturadas e fotografias. Em termos teóricos, o estudo busca amparo em escritos de autores do campo da Antropologia, Ciência da Religião e da Educação, tendo como recorte o ensino religioso. Os resultados indicam que a educação escolar e o catolicismo - no rio Mapuá entrelaçam-se por meio de rituais e artefatos sagrados que narram saberes, tradições, afetos, significados e simbologias que na percepção dos depoentes ajudam a forjar a formação escolar dos sujeitos e, por conseguinte, à cultura escolar.
\end{abstract}

Palavras-chave: Educação. Escola. Religiosidade. Simbolismo. Marajó.

\begin{abstract}
This study approaches the relationship between school education and Catholicism in rural areas, especially in the Mapuá river, Breves municipality, Marajó archipelago, Pará state. We have as objective to identify the presence of Catholicism in field schools. and the relationship with the formation of the students. Specifically, the perspective is to discuss the influence of religious rituals and sacred artifacts on the educational process and school culture. It is a qualitative research, based on bibliographic foray and field research, whose empirical data were collected through ethnographic observations, semi-structured interviews and photographs. In theoretical terms, the study seeks support in the writings of authors from the field of Anthropology, Science of Religion and Education, and it has religious teaching as its focus. The results indicate that school education and Catholicism in the Mapuá River are interlaced through rituals and sacred artifacts that narrate knowledge, traditions, affects, meanings and symbologies that in the perception of the deponents help to forge the school formation of the subjects and, therefore to the school culture.
\end{abstract}

Keywords: Education. School. Religiosity. Symbolism. Marajó.

Artigo submetido em 30 de novembro de 2019 e aprovado em 10 de abril de 2020.

* Doutora em Antropologia pela UFPA. Professora adjunta da UFPA. País de origem: Brasil. E-mail: elyany2007@hotmail.com 


\section{Introdução}

O texto trata da relação do catolicismo com a educação escolar do campo no Marajó, com recorte específico da realidade dos ribeirinhos ${ }^{1}$ do rio Mapuá e área por ele banhada, no município de Breves, arquipélago de Marajó, estado do Pará. Breves é um dos municípios mais populosos deste arquipélago, com 92 mil e 860 habitantes (IBGE, 2010); devido à sua localização geográfica, é considerado a "porta de entrada à extração de muitos haveres" (SARRAF-PACHECO, 2009, p. 89). Está situado no corredor Belém-Macapá, ocupando posição estratégica dentro da região, pois se encontra no cruzamento das rotas; no passado, de acordo com a historiografia, constituiu-se em um importante trunfo da colonização.

Por meio de seus Estreitos, os portugueses assumiram o domínio do vale verde, de modo a afastar toda e qualquer ameaça, o que inclui outros grupos europeus - sobretudo os holandeses - e a população local; no caso, as diferentes nações indígenas ${ }^{2}$, que foram em parte dizimadas e/ou escravizadas. Nessa conquista, cabe destacar a importante participação da Igreja Católica, por meio dos padres jesuítas, em especial, Antônio Vieira, considerado o pacificador dos índios.

Narram as memórias escritas que este religioso viajou ao rio Mapuá, localizado a 70km do espaço urbano de Breves, no ano de 1669, para negociar a pacificação com os Mapuá, os indígenas que mais resistiram às investidas dos portugueses. A negociação de paz foi feita com o cacique Piyé Mapuá, representante da federação de sete cacicados (Anaja, Aruã, Camboca, Guianá, Mamaianá, Mapuá, Piixi-Pixi) das nações Nheengaíba (SCHAAN, 2009), na localidade, hoje conhecida por vila Amélia, margem esquerda do rio Mapuá. Isso indica ser o Mapuá um importante cenário na escrita da história Amazônida, o que justifica nossa escolha para realizar esta pesquisa.

\footnotetext{
${ }^{1}$ Adoto a expressão "ribeirinhos" para denominar o grupo social aqui estudado, não por seus membros viverem às margens do rio, mas - principalmente - por o termo marcar a relação que tais agentes estabelecem com o meio ambiente amazônico, fato que se dá por vínculos simbólico-práticos, simbólico-religioso e afetivos de pertencimento com o lugar (COSTA, 2018).

${ }^{2}$ Antes da Colonização, viviam no Marajó várias nações indígenas. Essas formavam dois grupos: Aruãn, no lado, oriental e Nheengaíba, no lado, ocidental. O primeiro falante de língua Arawak adentrou no Marajó 200 anos antes da Colonização. Os Nheengaíba, vistos como "gente de língua incompreensível" (SCHAAN, 2009, p. 33), era grupo composto por 29 nações indígenas diferentes (Anajá, Mapuá, Pacaucaca, Guajará etc.), que podem ter migrado dos Andes à região. (SARRAFPACHECO, 2009).
} 
As pazes dos Mapuá foram mediadas pela imagem do Santo Cristo usada por Vieira, o que rendeu ao religioso a confiança dos indígenas e a garantia aos portugueses do domínio da região. (SARRAF-PACHECO, 2009). Desde então, as práticas religiosas de orientação católica ocidental passaram a fazer parte do universo desses povos, perpetuadas e ressignificadas - atualmente - pelos diferentes grupos, a exemplo dos ribeirinhos do rio Mapuá, prováveis descendentes das nações indígenas.

Nesse rio e nessa área existem, 15 comunidades católicas, e cada uma tem uma santa e/ou santo padroeiro/a, que - inclusive - dá nome à comunidade; quase sempre, às escolas. Ao longo do ano, essas comunidades festejam seus padroeiros, evento que leva em média nove dias e envolve quase todas as famílias; nesse momento, a dedicação deve ser ao santo/santa protetor/a. Além das festividades destacam-se, os artefatos de fé, os quais agem sobre o comportamento dos sujeitos. Uma Cruz, chamada de milagrosa, configura-se como o principal símbolo de fé e proteção do lugar.

Diante do exposto, este texto objetiva identificar a presença do catolicismo na escola do campo no Mapuá e a relação com a formação dos ribeirinhos, bem como discutir a influência dos rituais e artefatos sagrados no processo educativo e cultura escolar. O presente texto resulta da pesquisa de doutorado defendida em agosto de 2018 e realizada no contexto do rio Mapuá entre 2014 e 2018 no Mapuá.

A discussão proposta está organizada da seguinte forma: o primeiro tópico trata do percurso metodológico em que se destacam as fontes da pesquisa. Na sequência, mergulha-se em uma abordagem histórico-conceitual sobre educação e religião no estado brasileiro, dando ênfase às implicações da religiosidade no currículo, na formação e cultura escolar; o terceiro tópico, discorre sobre a presença religiosa na escola do campo e a relação com o processo formativo. Nas considerações finais, pontuam-se possíveis reflexões sobre os rituais e os artefatos sagrados como linguagem de ressignificação de cosmologias e cosmovisões, que orientam a produção de saberes e poderes locais e influenciam na formação escolar dos sujeitos e, por conseguinte, na cultura escolar. 


\section{Percurso metodológico}

Este é um estudo de caráter qualitativo, pois lida com um fenômeno que não pode ser reduzido a variáveis rígidas e imutáveis. Está fundamentado na incursão bibliográfica e pesquisa de campo, orientado pelo método da História Oral e abordagem Etnográfica. A pesquisa bibliográfica possibilitou levantar diferentes produções dos últimos três anos, acerca da temática em destaque. Tais estudos deram subsídios na discussão teórico-conceitual. A História Oral, assumida como "um procedimento, um caminho para produção histórica" (DELGADO, 2010, p. 16), foi fundamental para entendermos a pluralidade cultural e religiosa refletida nas ressignificações apresentadas pelos ribeirinhos. Seguindo Geertz (2012), assumi a etnografia como uma tentativa de fazer uma leitura do fenômeno religioso na relação com a escola, a partir do diálogo com as pessoas e o contexto.

Pautada em tais aspectos, coletei importantes narrativas orais por meio de entrevistas semiestruturadas. Na realização das entrevistas, fiz uso de um roteiro flexível, com cinco perguntas-chave, com foco na relação religião e educação. Essas aconteceram nas casas dos interlocutores, conforme combinado e gravadas com o devido consentimento, inclusive com assinatura do Termo de Consentimento Livre Esclarecido. Ao todo foram seis interlocutores, escolhidos a partir dos seguintes critérios: saber contar sobre a história do lugar, residir na localidade por - no mínimo - dez anos e ter disponibilidade em participar da pesquisa. Tais interlocutores estão identificados no texto com nomes fictícios, para assegurar o sigilo de suas identidades. As entrevistas foram transcritas de modo literal, sendo suprimidas as repetições; para efeito deste texto, selecionei trechos de tais entrevistas que atendessem aos objetivos propostos.

Outra fonte são as observações etnográficas, devidamente registradas no diário de campo. Para efeito deste texto, as observações correspondem às descrições da festividade religiosa de Santa Maria, na Comunidade de mesmo nome, um ritual, aqui interpretado como religioso, cultural, econômico e político. A descrição inclui também aspectos empíricos observados no decorrer de 2015 a 2017 
acerca da relação dos moradores com a Cruz Milagrosa, artefato mágico-religioso que tem agência sobre as pessoas; por conseguinte, influência no comportamento e na formação.

Recorremos ainda ao uso de fotografias, as quais caracterizam-se - neste estudo - como narrativas visuais, cuja função consiste em ampliar a comunicação e expressão acerca do fenômeno estudado. (BONI; MORESCHI, 2007). As fotografias foram capturadas com câmera semiprofissional durante o percurso etnográfico. Da combinação desses dados com a base teórica sob a perspectiva da análise interpretativa erigiu-se esta discussão.

\section{Educação e religião no estado brasileiro: uma abordagem histórico-conceitual}

De acordo com a historiografia, a religião católica de orientação ocidental, no passado, por meio dos padres jesuítas da Companhia de Jesus (guiados por pressupostos da retórica e da escolástica), constitui-se em estratégia fundamental da Coroa Portuguesa na conquista do território brasileiro. Dentro desse quadro, no tocante à Amazônia, em especial a marajoara, a figura de Padre Antônio Vieira foi emblemática. Este religioso, como citado, teve papel decisivo na negociação de paz com os indígenas marajoaras o que demonstra que Vieira desenvolveu a função de articulador político da Coroa Portuguesa, ato esse que contribuiu para fortalecer o poder do rei (D. João III) e promover a articulação entre fé e conjuntura política (FAGUNDES, 2018).

Pode-se dizer que essa articulação ganhou outra dimensão, falo dos colégios e seminários criados no Brasil, pelos padres jesuítas. Nessas instituições, com o objetivo de instruir para catequizar, tais religiosos aproveitaram para divulgar o "Cristianismo e a cultura europeia” (PIANA, 2009, p. 58), ideal para se alcançar os objetivos da colonização. Estado e Igreja católica apresentam-se - desse modo articulados, integrados e com propósitos bem definidos: "converter o índio à fé católica por intermédio da catequese e do ensino de ler e escrever português”. (SHIGUNOV NETO; MACIEL, 2008, p. 171, grifos dos autores). 
A ideia de um possível "divórcio" entre Estado e religião católica começa a ser fomentada com a expulsão dos jesuítas, momento em que o Estado assume a educação, até então a cargo desses religiosos. Essa separação entre Estado-Igreja foi instituída oficialmente pela Constituição Republicana de 1891, a qual determinou que não haveria uma religião oficial no Brasil, bem como fez da escola de tradição jesuítica uma instituição pública, com princípios laicos, pelo menos na perspectiva da lei. Como salienta Valente (2017), tal separação foi por pouco tempo; com o Manifesto dos Pioneiros de 1932, o tema laicidade escolar ganhou destaque em um profundo e polêmico debate entre liberais e católicos.

Com maior poder, a corrente católica conseguiu inserir no currículo a disciplina Ensino Religioso (ER) em caráter facultativo por meio do Decreto $\mathrm{n}^{\mathrm{o}}$ 19.941 de 30 de abril de 1931, em função da Reforma Francisco Campos. A Constituição de 1934 manteve a inserção do ER, o que foi seguido pela Constituição de 1946, mas sempre acompanhado de muita polêmica. Avançando um pouco, chegamos a nossa última carta magna - a Constituição Federal de 1988 - que também mantém o ER, sem longe de superar o conflito que o assunto suscita. (VALENTE, 2017).

A literatura consultada sustenta a ideia de que a inserção e manutenção do $\mathrm{ER}$, embora de matrícula facultativa, não deixa de evidenciar a escola de hoje com certa tendência do modelo implantado pelos padres jesuítas. Nas palavras de Valente (2017, p. 200), "o modelo/estrutura da instituição escolar atual continua sendo um desdobramento de um modelo de escola jesuítica e religiosa”, ainda que esta escola tenha sofrido outras influências, a exemplo do pensamento positivista.

A influência cristã até o final do século XX, de acordo com Santos e Junqueira (2018), apresentava-se materializada em dois modelos: um confessional, de orientação católica amparada pela Lei de Diretrizes e Bases (LDB), $\mathrm{N}^{\circ}$ 4.024/1961 e o interconfessional, resultante da articulação de diferentes confissões cristãs, assegurado pela Lei $\mathrm{N}^{0} 5.692 / 1971$. Longe de superar a polêmica que a questão suscita, ambos os modelos foram mantidos na atual LDB, Lei $\mathrm{N}^{\circ}$ 9.394/1996. 
Com a Lei $N^{\circ}$ 9.475/1997, que altera o Art. 33 da LDB de 1996, a discussão se ampliou e ganhou outro elemento. Conforme tal lei, a organização do ER, entendido como componente curricular de matrícula facultativa, passou a ser de responsabilidade dos sistemas de ensino, tendo por referência os princípios e pressupostos das instituições e não mais das confissões religiosas. Essa medida é interpretada como necessária à garantia do princípio da laicidade, do Estado brasileiro. (SANTOS; JUNQUEIRA, 2018; CARNEIRO, 2018).

A questão é muito mais complexa do que parece; na prática, a lei só acrescentou uma vírgula a mais nesse imbróglio: transferir a responsabilidade de organização do ER aos sistemas estaduais e municipais de ensino, sem uma política de formação para os professores, não significa garantia da laicidade. É ingenuidade pensar a escola como espaço neutro; tanto os professores como os demais profissionais que atuam na escola têm uma concepção de religiosidade, que acaba por orientar o ER e - por conseguinte - a formação dos alunos.

Lembram Santos e Soares (2018, p. 77), que no ano de 2015, o ER praticado nas escolas públicas passou a ser "pauta de discussão nas Audiências do Supremo Tribunal Federal, diante da Ação Direta de Inconstitucionalidade ajuizada em 2010 pela Procuradoria-Geral da República” em função de práticas vistas como prosélitas e confessionais adotadas por algumas escolas ferindo a laicidade do Estado. Em 27/09/2017, o referido Supremo, negando a suposta inconstitucionalidade, definiu que o ER "deve ser disponibilizado não apenas como oferta escolar facultativa para os alunos, mas que nas escolas públicas, pode ser ligado a crenças específicas”. (CARNEIRO, 2018, p. 406)3.

Com esta decisão o Supremo abriu espaço na leitura de Carneiro (2018), para três alternativas do ER: o confessional, o não confessional e o interconfessional. O modelo democrático republicano de laicidade do estado brasileiro é - assim - polêmico e complexo, mas não deixa de ser estratégia de reconhecimento da diversidade cultural e religiosa no país. Uma pluralidade que

3 Decisão segundo Carneiro (2018), influenciado pelo acordo, firmado em 2008, entre o governo brasileiro e o Vaticano, o qual determina ser o ER, católico e de outras crenças religiosas, disciplina dos horários normais das escolas públicas. 
certamente corrobora uma possível formação crítico-emancipatória (SANTOS; SOARES, 2018), imprescindível ao combate à intolerância religiosa.

Cabe aqui, ao menos, duas considerações teórico-epistemológica. Primeiro, é um equívoco não pensar o ER como um componente curricular necessário e indispensável para uma formação que se queira integral, inclusiva e democrática. Na escola, como observam Ventura e Holmes (2018, p. 55) não se ensina religião, isso se faz em templos, "a escola é um espaço onde se adquire conhecimentos e entre estes está o conhecimento religioso", que os Parâmetros Curriculares Nacionais do Ensino Religioso (PCNER) definem como patrimônio da humanidade. (BRASIL, 2009).

Segundo, é igualmente enganoso entender o Estado como um ente absolutamente laico (sem orientação religiosa nenhuma), pois não podemos esquecer que é gerido por um grupo, com ideologias não só políticas. O discurso do atual governo e as mudanças na LDB (inclusão do Art. 7-A) exemplificam muito bem esse quadro. Como demonstrado aqui, nossa sociedade tem bases cristãs desde a Colonização e tentar retirar isso da história identitária é - de certo modo negar a milhões de brasileiros o direito em conhecer as raízes de sua formação cultural, histórica e humana. (CARNEIRO, 2018).

Isso significa dizer que o currículo escolar obrigatório, referendado por uma base nacional comum, não pode ocultar estudos acerca de elementos culturais fundantes da nação, como é o caso. Para isso, como tem sido defendido inclusive pela perspectiva da Ciência da Religião, o ER - por conseguinte, a religiosidade precisa ser interpretado como uma área de conhecimento potencial para que educadores e educandos possam reconhecer o outro e suas visões religiosas, além de ter condições de questionar o ocultamento de práticas religiosas dos variados grupos brasileiros, a exemplo dos indígenas, como também daqueles que se declaram sem religião. 
É válido pontuar que, em 2010, as Resoluções $n^{0}$ 04/2010 e a Resolução ${ }^{\circ}$ 07/2010 do Conselho Nacional de Educação assinalaram o reconhecimento do ER como uma das cinco áreas de conhecimento do Ensino Fundamental de nove anos. Desde então, é componente curricular obrigatório de matrícula facultativa, nas escolas públicas desse nível de ensino, e integra a Base Nacional Comum Curricular (BNCC), aprovada em 2017, como mostra o próximo tópico.

Ser um componente curricular obrigatório pode possibilitar ao ER articular com os outros campos de saberes e assim constituir-se em elemento da cultura escolar. O diálogo entre os campos é indispensável para fomentar e praticar uma educação, que priorize o respeito à diversidade cultural e religiosa. Daí a importância de apreender a laicidade como estratégia para potencializar a religiosidade enquanto campo de pesquisa no âmbito da escola. Na conjuntura atual, é cada vez mais necessário esse tipo de entendimento para que uma determinada ideologia religiosa não venha se tornar hegemônica, relegando as demais expressões e manifestações religiosas ao histórico silenciamento imposto pela colonização.

\section{Religião, religiosidade, currículo e cultura escolar}

Toda a polêmica em torno do ER e da suposta laicidade do Estado, com base na abordagem exposta aqui, tem um foco - o currículo escolar - exatamente por esse ser o elemento definidor da formação dos indivíduos. O currículo é quem diz o que ensinar ao sujeito e com qual intencionalidade. É um território em disputa (ARROYO, 2011), demarcado por relações de poder e jogos de interesses. Isso mostra que o currículo não pode ser visto e pensado no dizer de Silva (2007, p. 150) "com a mesma inocência de antes".

Para este autor, currículo

[...] tem significados que vão além daqueles aos quais as teorias tradicionais nos confinaram. O currículo é lugar, espaço, território. $\mathrm{O}$ currículo é relação de poder. O currículo é trajetória, viagem, percurso. O currículo é autobiografia, nossa vida, curriculum vitae: no currículo se 
forja nossa identidade. O currículo é texto, discurso, documento. O currículo é documento de identidade. (SILVA, 2007, p. 150).

No contexto escolar, o currículo enquanto esse território de poder do qual fala o autor, tem sido pensado como espaço de saberes, conhecimentos e concepções, desconectados de experiências e vivências concretas, ou seja, distante dos agentes produtores de tais vivências. Essa dicotomia se observa mais ainda quando nos reportamos à realidade rural, cuja escola historicamente tem se resumido em arremedo da escola urbana. (ARROYO, 1999).

Assim é uma escola de orientação urbanocêntrica, que tem enfrentado dificuldades para dialogar com o saber local (GEERTZ, 1997). No contexto amazônico, uma das dificuldades nesse aspecto refere-se à questão religiosa, fenômeno que - nas comunidades rurais - caracteriza-se como uma marca profunda das populações tradicionais. Quero dizer com isso que as comunidades rurais são movimentadas pelas crenças aos santos, pelas pajelanças, pelos artefatos sagrados e, também, pelos cultos evangélicos. São rituais que transcendem ao espiritual, abarcam outras dimensões (política, econômica e cultural) e que, mesmo não se dando conta, a escola acaba por ser enredada nessa dinâmica.

Esse processo envolve não só o caráter institucional da religião; abarca, sobretudo, a religiosidade. De acordo com Valente, a religião em seu caráter institucional, influenciou de forma profunda na organização da sociedade, "estabelecendo categorias de pensamento e de julgamento, indicando formas de ação e uma 'verdade' única que se afirmaria para além daquilo que é material, natural, concreto e finito" (VALENTE, 2017, p. 102-103). Isso sugere que a religião tem forte influência em outras instituições, tal como a escola.

Embora a religião transcenda a Igreja, para entender as diferentes manifestações religiosas, inclusive na escola, faço uso do termo religiosidade que conforme a autora citada - configura-se como uma dimensão que interliga as diferentes instituições, das quais os indivíduos não só circulam, mas constroem experiências. Religiosidade é, desse modo, "aberta, dinâmica, sincrética e se 
diferencia do conceito de religião" (VALENTE, 2017, p. 201), o qual entendemos como um conceito mais fechado, o que nos ajuda a explicar a intolerância religiosa.

Na particularidade do rio Mapuá, durante vivências etnográficas, observei uma interligação entre igreja e escola por meio de rituais, simbolismos, compreendendo assim a chamada religiosidade. Registra-se que - em dia de festejos religiosos - as escolas normalmente suspendem suas atividades, para que os alunos se dediquem aos rituais da igreja. Em alguns casos, os professores que não são da localidade também participam de tais rituais; em outras situações, aproveitam para viajar à cidade.

Em diálogo com alguns dos docentes, os mesmos revelaram que dificilmente debatem com os alunos sobre os festejos e símbolos como fenômeno de estudo, muito em função da laicidade, como argumentou J.P, professor dos anos iniciais. Esse fenômeno que - historicamente - causa conflitos e que vêm sendo negado; sobretudo pelo governo, que não reconhece o Estado laico. Prova disso é o acréscimo do Art. $7^{\circ} \mathrm{A}$ na $\mathrm{LDB}$ vigente que assegura ao aluno, regulamente matriculado, ausentar-se da escola sem prejuízos em função de seus preceitos religiosos.

Esse não-diálogo permite indicar o currículo escolar como um produto abstrato, que, na perspectiva de Arroyo (2011), consagra-se na clássica dicotomia base comum e diversificada. A base comum é definida por este autor como "conhecimento que não trazem as marcas das diversidades regionais ou da diversidade de contextos concretos de lugar, classe, raça, gênero, etnia” (ARROYO, 2011, p. 77) e religiosidade. Tem caráter universal, enquanto a base diversificada se refere aos outros, não universais e não obrigatórios, como os saberes e práticas locais, pouco evidenciados na cultura escolar.

A BNCC da educação infantil e ensino fundamental, aprovada em 2017, oficializa essa universalidade, com uma política educacional de currículo que supostamente - integra as três esferas (federal, estadual e municipal) da educação 
nacional, com foco na formação docente, avaliação e seleção de conteúdos. Para tanto, no tocante ao ER, este documento traça os seguintes objetivos:

a) Proporcionar a aprendizagem dos conhecimentos religiosos, culturais e estéticos, a partir das manifestações religiosas percebidas na realidade dos educandos;

b) Propiciar conhecimentos sobre o direito à liberdade de consciência e de crença, no constante propósito de promoção dos direitos humanos;

c) Desenvolver competências e habilidades que contribuam para o diálogo entre perspectivas religiosas e seculares de vida, exercitando o respeito à liberdade de concepções e o pluralismo de ideias, de acordo com a Constituição Federal;

d) Contribuir para que os educandos construam seus sentidos pessoais de vida a partir de valores, princípios éticos e da cidadania. (BRASIL, 2017, p. 434).

Tais objetivos podem ser analisados como estratégicos para tratar as diferentes identidades culturais e religiosas que transitam no espaço escolar como fenômeno de estudo, o que - até então - pouco se faz; essas diretrizes traçam como competências necessárias. Porém, precisamos analisar tal fato com bastante cuidado, isso porque, a determinação de competências pode indicar muito mais o desenvolvimento de um ER pragmático do que um ensino que valoriza a diversidade religiosa e cultural. Entendo que, para dar ênfase às diversas identidades culturais e religiosas no âmbito da escola pública, precisamos superar o reducionismo das competências. A escola precisa abrir espaço para questionar os processos e mecanismos de homogeneização, uniformização, ocultação da diversidade cultural e religiosa sob a égide da colonialidade.

Para isso, faz-se necessário dar-se conta da importância de se investir em uma formação que permita ao educador exercitar de fato outros olhares acerca da própria prática. Em outras palavras, faz-se urgente uma formação que possibilite a este profissional entender que "ser docente-educador não é ser fiel a rituais preestabelecidos, mas se guiar pela sensibilidade para o real, a vida real, sua e dos educandos e criar, inventar, transgredir em função de opções políticas, éticas”. (ARROYO, 2011, p. 51). 
Isso implica o desafio de entender que a educação escolar não está descolada da vida em sociedade. A escola - na verdade - é ferramenta da sociedade; a religiosidade que, como citado, envolve vivências, experiências, obtidas não só em instituições religiosas, mas, também, em outras instituições, não está alheia à escola e sua cultura (VALENTE, 2017). Esse é um desafio que demanda paradigmas, teorias, concepções que valorizem o diálogo e permita ao docente pensar e exercitar a docência e o currículo como construções sociais criativas.

Como nos lembra Freire (2007, p. 90), “a existência, porque humana, não pode ser muda, silenciosa, nem tampouco pode nutrir-se de falsas palavras, mas de palavras verdadeiras, com que os homens transformam o mundo". Nessa perspectiva, o ER precisa ser reconhecido como fenômeno cultural, conforme indicam os estudos antropológicos. Enquanto elemento cultural envolve símbolos, significações, concepções e lógicas específicas, que enredam os sujeitos e forjam sua natureza humana. (GEERTZ, 2012).

O estudo do ER como objeto possibilita ao educando perceber que sua identidade tem sustentação em uma pluralidade axiológica, da qual faz parte o respeito à vida (em todas suas formas), ao modo de ser, estar e habitar no mundo. Inclui o respeito ao ambiente, às diferentes perspectivas de mundo, à cultura e suas diversas manifestações e à humanidade. Uma educação alheia a essa pluralidade dificilmente - promoverá uma formação crítica, integral, inclusiva e democrática.

Uma formação nesses termos deve possibilitar ao educando condições epistemológicas de dialogar com as diferentes manifestações culturais e religiosas (inclui os que não têm religião), percebendo que não existe uma cultura e religião mais verdadeira ou superior. Para isso, a escola - na organização de seu currículo deve pensar e incluir o ER, tendo como pressuposto básico o conhecimento como um processo sempre em construção e a diversidade cultural e religiosa como elementos inerentes ao existir humano; por conseguinte, da cultura escolar. 
Pautado nessa perspectiva, o ER na escola pode oferecer aos estudantes e professores condições de potencializar esta instituição como palco do diálogo, condição sine qua non para que esses agentes possam aprender a conviver com as diferenças e promover a cultura de paz. Alunos, professores e demais agentes precisam entender a escola como o espaço onde se pode adquirir e construir conhecimentos. Isso significa tecer histórias, conhecer memórias e desenvolver-se como ser humano.

Para isso, a religiosidade deve ser interpretada como uma das várias linguagens humanas imprescindíveis para promover o respeito ao outro, às diferenças. Religião e religiosidade não podem ser estratégias de manutenção de poder, interesses e necessidade de um grupo, uma classe. $\mathrm{O}$ aspecto religioso deve, desse modo, ser valorizado e entendido como um elemento da vida humana que envolve tradições enredadas em cosmologias e cosmovisões, tal como mostra o tópico abaixo.

\section{A escola do campo e o Catolicismo: simbolismo e rituais no Rio Mapuá}

O Mapuá é um dos rios mais extensos de Breves; embora não seja o único neste município, suas histórias, memórias, tradições e vestígios de distintas temporalidades não deixam de ser significativas para conhecermos a região. No passado, este rio acomodou, nas entranhas de sua floresta, nas curvas e estirões de seus igarapés e na dimensão de seus lagos, os indígenas Mapuá, o que ajuda explicar o nome atribuído ao rio e à área por ele banhada (COSTA, 2018). Como mencionado anteriormente, o Mapuá foi palco de negociação entre indígenas e portugueses, o que faz deste território um importante marco da história e memória da Amazônia paraense e marajoara.

Este rio está localizado a $70 \mathrm{~km}$ - em linha reta - do núcleo urbano do município de Breves e banha a maior parte da área onde foi criada a Reserva Extrativista Mapuá, por meio de Decreto Presidencial s/n de 20/05/2005. Nos dias atuais, esse rio acolhe, em suas margens, diferentes famílias organizadas em 
comunidades de pequena escala (BEZERRA, 2011). Ao todo são 16 comunidades; desse total, 15 são de orientação católica, logo, cada uma tem um santo ou santa padroeira. Em suas sedes (ou vilas de referência), encontram-se as igrejas e as escolas, instituições que conferem às famílias o status de comunidades. A pesquisa se concentrou nas vilas e comunidades de Santa Maria, Nossa Senhora de Nazaré e Santa Rita, reconhecidas pela Paróquia Sant’Ana na cidade Breves.

O reconhecimento da comunidade Santa Maria ocorreu em 1983, ano de fundação da Igreja. Anos depois (1997), atendendo à reivindicação da comunidade, a prefeitura abriu a escola municipal Santa Maria, com matrícula apenas nos anos iniciais do ensino fundamental, anos depois a escola foi reformada passando a atender também os anos finais desse nível de ensino. No caso da comunidade Santa Rita, tal reconhecimento ocorreu um pouco antes - no ano de 1978 - quando a Igreja também foi criada. No ano seguinte (1979), nessa comunidade, foi criada a primeira escola pública no Mapuá, organizada em classes multisseriadas (hoje multianos, compreende alunos de diferentes níveis de aprendizado e faixa etária, conduzidos por um único professor).

Em relação à comunidade Nossa Senhora de Nazaré, só em 1984 foi reconhecida como tal; nos anos 2000, a escola de primeiras letras passou a fazer parte deste cenário. Com exceção de Nossa Senhora de Nazaré, nas demais comunidades, o prédio da escola e o da Igreja ficam lado a lado, fenômeno recorrente na realidade rural da Amazônia. Outro elemento bastante comum é o nome das escolas, que quase sempre leva o nome da comunidade - do santo ou da santa padroeira. Nessa dinâmica, a igreja, em todas as comunidades, criadas primeiro que a escola, desempenha, no entendimento de seu Josué (2017), “o papel de evangelizar e socializar as famílias”, mas, também de contribuir com a formação educativa dos sujeitos, conforme entende JP, professor de classes multisseriadas. Argumenta seu Josué: “A Igreja nos une como comunidade e assim a gente consegue as coisas [...], conseguimos a escola, que tem o papel de ensinar nossos filhos. Eu digo assim, essas duas instituições são muito importantes pra nós, pro nosso desenvolvimento." 
Entre as leituras que a narrativa sugere, podemos dizer que Igreja e escola no Mapuá promovem o desenvolvimento social e cultural das comunidades. Estas instituições são próximas não apenas no aspecto geográfico; na verdade, elas estão entrelaçadas, enredadas em uma teia de saberes com igual importância para o crescimento das comunidades. Igreja e escola na perspectiva dos moradores têm importância ímpar no desenvolvimento da comunidade, sobretudo, à escola, como narra seu Antônio:

Muitos de nós não sabia ler, nossos filhos também não e, a gente queria ler na Igreja [...], então criaram a escola [...]. É um direito de nossos filhos, né. Hoje já tem gente dando aula, fazendo outros trabalhos, estudaram aqui [...]. Então, a gente precisa da escola pro nossos filhos se desenvolverem e a comunidade também [...]. Sem a escola nossa comunidade não se desenvolve, porque aí o pessoal vai embora, manda os filhos pra cidade [...]. A escola nos desenvolve, né.

Na compreensão dos interlocutores, Igreja e escola desempenham funções específicas, mas que não dissociam totalmente, pois lidam com a formação e a sociabilidade dos sujeitos. Os interlocutores permitem chamar atenção para o aspecto cultural da religiosidade o que visualizamos com mais detalhes nas festividades, uma marca da Igreja católica em todo o Mapuá. Um ritual responsável por movimentar e integrar as famílias entre si; com outros grupos o ano inteiro, o que também indica um processo formativo.

Em Santa Maria, a festividade religiosa ocorre de seis a 15 de agosto, em Santa Rita, de 14 a 22 de maio e, em Nossa Senhora de Nazaré, de primeiro a oito de setembro. Acompanhei parte desse ritual em Santa Maria em agosto de 2017. Durante esse percurso etnográfico, pude notar que as comunidades próximas participam ativamente, já as que ficam distante nem sempre comparecem, embora sejam convidadas. Cada comunidade é responsável pela condução de uma noitada (envolve realização da novena, vendas de comida e jogo de bingos). É um momento de celebração religiosa e cultural quando se estreitam os laços, estabelecem-se acordos, combinados, namoros, entre outros. Além dos vizinhos, as festividades atraem políticos, empresários e curiosos da cidade, constituindo-se assim em um verdadeiro intercâmbio cultural. 
$\mathrm{Na}$ festividade de 2017, ano que realizei essa etnografia, os professores, filhos da comunidade, com ajuda dos alunos, participaram ativamente desse rito. Durante todo o período, que se estendeu por dez dias, professores e alunos fizeram vendas, realizaram leituras na igreja, organizaram bingo, torneios de futebol e várias brincadeiras com o intuito de integrar as comunidades. Nesse movimento, o prédio da escola foi utilizado, nos últimos três dias, como alojamento para as famílias visitantes. Nesses dias, as aulas foram suspensas tanto na escola local quanto na escola da comunidade Nossa Senhora de Nazaré, com a finalidade de os professores (que atuam em ambas as escolas), e alunos se dedicassem à festividade e suas atividades, considerado pelos depoentes como um processo educativo.

\title{
Relatou o professor Rogério:
}

\begin{abstract}
Nesses dias temos que nos envolver com as coisas da comunidade, da Santa, que nos protege. A escola é laica, nós sabemos, mas isso aqui é também cultural, é as nossas raízes, que a escola tem a função de ajudar a valorizar. Eles foram orientados a fazer atividades de leitura para discutirmos na próxima aula. A escola não pode tendenciar, mas não pode também ignorar isso [...]. Até porque, é diferente né, na escola a gente fala sobre religião, não prega.
\end{abstract}

O depoente chama atenção para uma importante questão que não se pode deixar de considerar; na escola, a religião é fenômeno de estudo e não de evangelização. Ter consciência sobre essa dimensão é fundamental para reconhecer a diversidade religiosa, aspecto indispensável para superar preconceitos de cunho religiosos. A narrativa bem lembra que a escola é um espaço de produção e socialização de conhecimentos. Por isso, deve ser um espaço plural, que "em seus processos de ensino e de aprendizagem, considere o universo cultural e as formas próprias de aprendizagem dos povos do campo" (ANTUNES-ROCHA; DINIZ; OLIVEIRA, 2011, p. 23).

Consoante o pensamento partilhado pelo professor Otávio, 
[...] a escola tem um papel fundamental na vida da comunidade [...], influência totalmente no nosso desenvolvimento [...]. Como professor me vejo como peça importante nesse desenvolvimento [...], então não posso ensinar desvinculado da realidade local [...]. Aqui a religião católica, a religiosidade é muito forte, não tem como a escola ignorar isso [...]. Nós temos um currículo transportado do meio urbano para o meio rural [...], então, cabe a nós trabalhar os conteúdos dialogando com à realidade, e as festividades fazem parte dessa realidade. [...]. As festividades, além de ser um período quando professamos e renovamos a fé, é também um momento que realizamos um encontro cultural. Realizamos brincadeiras para integrar as comunidades. Brincadeiras tradicionais que têm perdido espaço até na própria escola, mas que têm a função de integrar e socializar as famílias. Então não é só religioso, é cultural, e a escola tem muito a contribuir com essa dinâmica cultural e religiosa das famílias.

Como instituição responsável pelo processo educativo, a escola não pode ignorar as experiências e vivências do sujeito, e parte desses aspectos é fruto de religiosidades. Continuando com o mergulho etnográfico, registra-se que no último dia de festa as famílias realizaram a tradicional procissão. Esse ritual iniciou com a caminhada por toda vila, carregando a imagem da santa em seu ardor enfeitada de flores, acompanhado de orações e cânticos. A figura 1 narra o momento em que a procissão passou por trás das casas. Após percorrer toda a vila, a imagem foi conduzida de volta à Igreja para a celebração final (figura 2).

Figura 1 - Procissão da festividade de Santa Maria, rio Mapuá

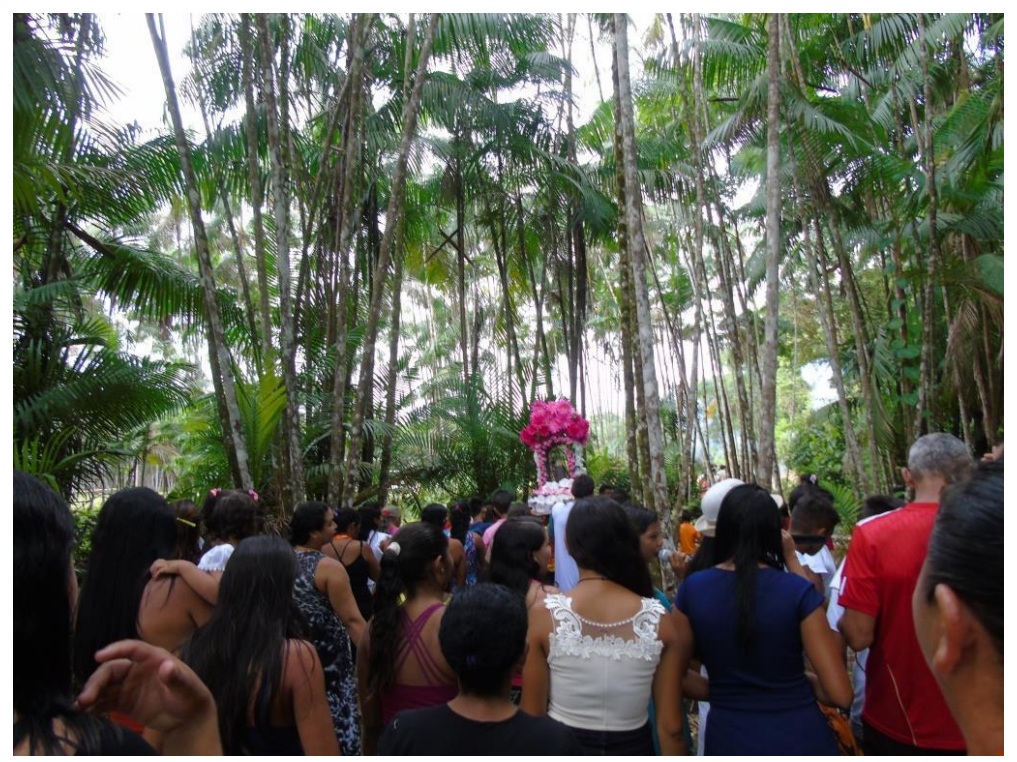

Fonte: Arquivos da Pesquisa, 2017. 
Figura 2 - Celebração final da Festividade de Santa Maria, rio Mapuá.

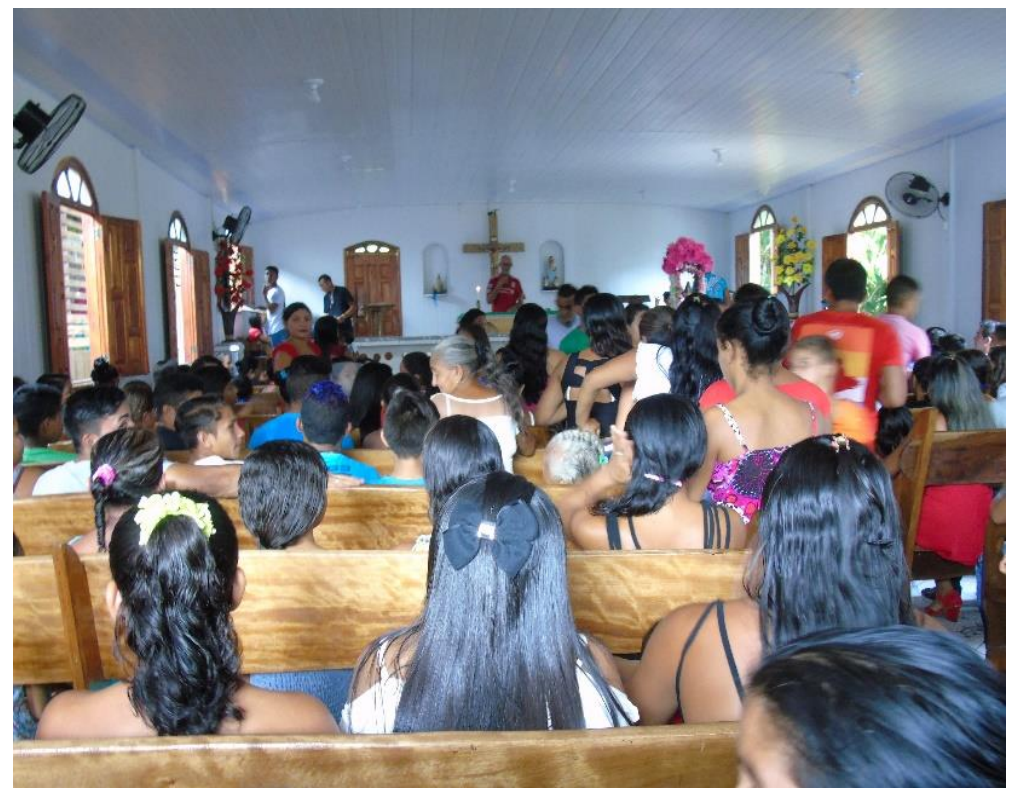

Fonte: Arquivos da Pesquisa, 2017.

Ambas as figuras narram um processo educativo-religioso que envolve além da caminhada - a forma como os devotos tratam a imagem da santa. Há todo um cuidado e respeito por parte dos adultos sobre o que é ensinado às crianças. Durante a procissão e a celebração, observei que muitas pessoas levam suas oferendas (fitas, dinheiro, etc.) como retribuição à proteção e aos milagres recebidos. As vendas feitas para arrecadar recursos à Igreja são extensão dessa retribuição, bem como todo o esforço de promover a festividade que os depoentes entendem como expressão e ritual religioso e cultural das famílias.

Trata-se de uma dinâmica que enreda homens, mulheres, adultos, jovens, idosos e crianças em uma linguagem que não é só religiosa, no sentido do termo, mas um processo educativo dos quais se valem os sujeitos com o qual ensinam e aprendem como lidar com o natural e o sobrenatural. Isso mostra que a religião transcende o âmbito da instituição igreja (VALENTE, 2017) e do próprio ritual sagrado, configurando-se como uma dimensão simbólica e educativa com a qual o grupo ressignifica seu modo de vida. 
No transcurso dessa etnografia, observei que a festividade é um ritual que mexe com todas as pessoas. Elas colocam suas melhores roupas, organizam suas casas, fazem juntas as refeições. Então, além de ser um ritual para renovar e professar a fé como expressou o professor, é um momento de aproximação das famílias, de sociabilidade, de troca, de contato entre as pessoas e entre as coisas e as pessoas. Na definição de Wagley (1988, p. 206), "os dias de santo constituem pretexto para reuniões sociais e comemorações, seguindo os costumes herdados de Portugal e - posteriormente - modificados no processo de adaptação às novas condições"; no caso, em particular, ao regime de rio e floresta.

Na dinâmica dos ritos religiosos por entre rio e floresta no Mapuá, além dos artefatos sagrados encontrado nas igrejas e em pequenos altares nos diferentes lares, chama atenção a Cruz Milagrosa, um poderoso símbolo da religiosidade mapuaense, que as famílias recorrem em diferentes situações: para curar de alguma doença, arrumar casamento, comercializar, fazer uma boa colheita, entre outros. Essa Cruz em madeira está localizada às margens do rio Mapuá; para os devotos, caracteriza-se como uma espécie de recompensa, que pode ser interpretada como uma justiça divina (SALLES, 2019), já que - historicamente - o lugar e as pessoas vêm sendo vítimas da ganância do capital.

Como não há um serviço de saúde pública que atenda às necessidades da população, a Cruz - ao atender os milagres - sobretudo, curar os males dos corpos daqueles que a procuram, promove a justiça que foi negada a tais sujeitos. Em outra perspectiva, esse artefato pode ser também, interpretado como instrumento que liberta os sujeitos que recebem o milagre dos pecados cometidos (SALLES, 2019). Esse símbolo tem uma força, um poder que produz efeitos na vida das pessoas, inclusive à distância, o que se observa na vinda de pessoas de outros lugares que durante o ano passam pelo Mapuá para pagar promessas.

Como se observa na figura 03, as oferendas deixadas na Cruz na condição de recompensa do milagre recebido são em sua maioria roupas e fitas. É dessa forma que as pessoas respondem a dádiva recebida através do artefato que pelo 
expressado pode ser definido como mágico-religioso. Com as observações e narrativas, foi possível perceber que tal artefato é bastante requisitado pelas famílias; dentre os milagres o que mais se atribuem à Cruz, está a cura de crianças e mulheres grávidas.

Figura 3 - Cruz Milagrosa, rio Mapuá.

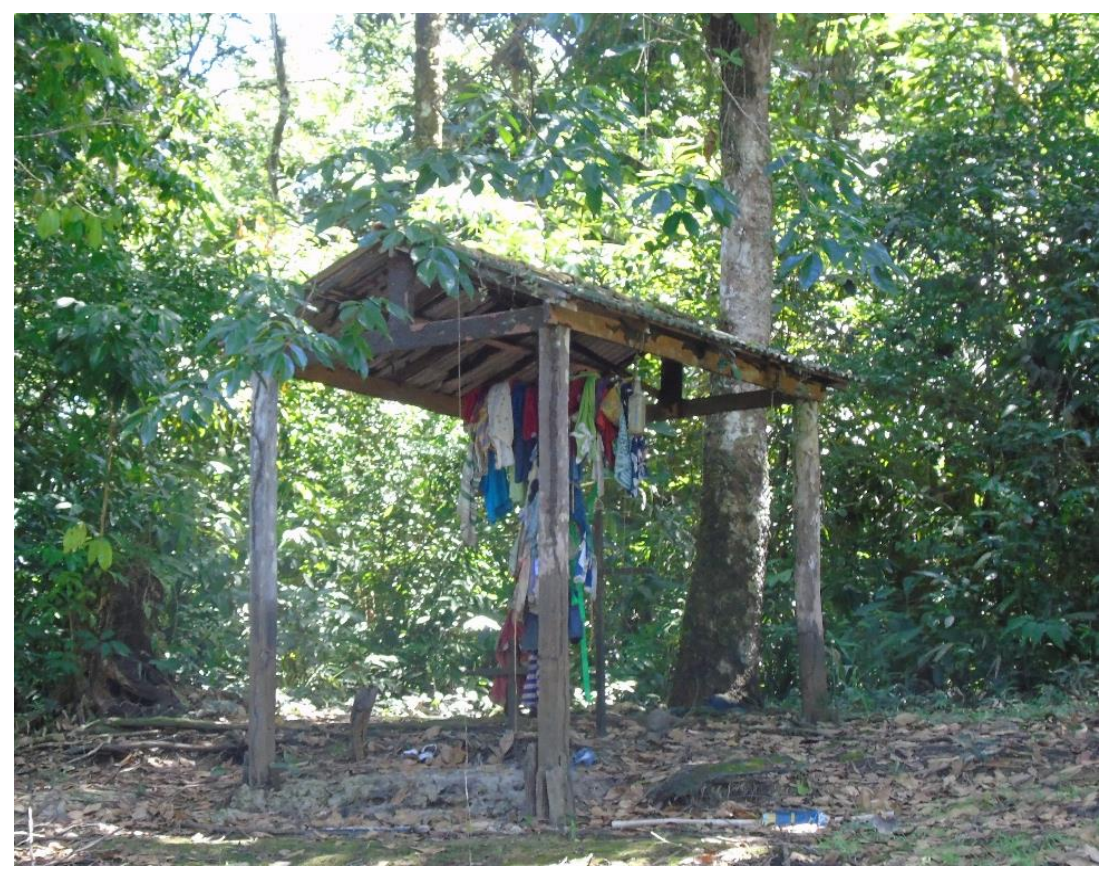

Fonte: arquivo da pesquisa, 2017.

Em diálogo com dona Jandira, uma das moradoras mais antiga da comunidade Santa Rita, a mesma revela que essa Cruz se tornou milagrosa após um padre rezar uma missa sobre o sepultamento de um homem desconhecido que foi encontrado e enterrado no local onde está a Cruz. O suposto padre - em ato sacramental - transformou a referida cruz em artefato sagrado para que as pessoas que passassem por ali não sentissem medo ao saberem do ocorrido; ao contrário, que se sentissem protegidas. Assim, começou a história da Cruz Milagrosa, conforme dona Jandira; desde então, esse poderoso artefato - elemento da cultura material dos ribeirinhos no Mapuá - é um importante símbolo da religiosidade local e tem a função de cuidar e proteger as pessoas e o lugar. Na verdade, tem a função de mediar a relação entre o humano e o cosmo, agindo assim sobre o comportamento dos sujeitos. 
Tratando especificamente de um milagre recebido, dona Jandira narrou: "minha filha fez promessa para o filho dela. Ele tava com febre, bem doentinho. Assim que ela se pegou com a Cruz ele ficou curado. Ela levou fita e vela de promessa [...]. Essa Cruz faz milagre mesmo. Não tem uma criança que não foi curada [...]. Todos que pedem pra ela, cura mesmo".

A narrativa, a figura 3 e as observações etnográficas permitem afirmar que a Cruz Milagrosa participa da vida religiosa e cultural desse grupo, assim como os demais artefatos sagrados e os rituais, como a festividade mencionada. Essa Cruz é uma das manifestações e símbolos da experiência sagrada das famílias e, como tal, também desempenha a função de educar no sentido amplo, não restrito ao âmbito escolar, mas que de certo modo não deixa de se fazer presente na escola.

\section{Considerações finais}

Toda a dinâmica narrada permite mostrar como o ritual do catolicismo é praticado no Mapuá e qual o efeito que a religiosidade desempenha sobre os modos de vida na floresta. Tal como identificaram Galvão (1955) e Wagley (1988) em Gurupá, no Mapuá, prevalece um catolicismo marcado pela devoção aos santos, cultos, romarias e festividades em honra aos seus/suas padroeiros/as articulado ao modo de vida local, o que inclui também o papel dos benzedores. São atividades não reduzidas à religião católica, mas que partem dela se e articulam-se aos demais aspectos da formação humana, fato que faz do ritual religioso elemento imprescindível para a construção identitária de cada indivíduo, família e comunidade.

Em uma leitura interpretativa dos aspectos religiosos e culturais narrados, é possível sugerir que estes elementos se apresentam alinhados à força das crenças e das práticas de um catolicismo popular, sincronizadas aos segredos de rios e floresta. Como argumentam Sarraf-Pacheco (2009) e Maués (2005), não é possível -, no contexto amazônico (resguardando a complexidade do termo) - tratar desse catolicismo descolado dos saberes locais, orientadores das práticas culturais e relações do existir humano. Nesse aspecto, não é possível tratar o processo 
educativo desenvolvido na escola desvinculado desse universo que, como mostrado, é dinâmico, múltiplo e transcendental.

Atentando para os objetivos aqui propostos, pode-se constatar que - no Mapuá - o catolicismo se faz presente na escola, não de forma direta como objeto de estudo. Essa presença pode ser identificada por meio dos rituais e artefatos sagrados, os quais têm influência sobre o comportamento dos sujeitos. Em outros termos, pode-se dizer que a religiosidade, que vai além da noção de religião em sua perspectiva institucional, tem uma profunda relação com a escola, ainda que isso não seja tão explícito do ponto do currículo oficial. É possível afirmar que a religiosidade se faz presente na escola pela própria dinâmica que enreda a comunidade. Escola e Igreja são para os ribeirinhos símbolos de reconhecimento da comunidade e - principalmente - instituições responsáveis pelo processo formativo.

A religiosidade tem, nesse quadro, influência direta na formação dos sujeitos, fato que podemos constatar com os rituais e os artefatos usado com maior frequência. Nesses termos, pode-se dizer que a laicidade tem um importante papel a desempenhar; para isso, a laicidade não deve se restringir à exclusão das manifestações religiosas do espaço escolar: a laicidade precisa ser assumida como mecanismo de reconhecimento das práticas, visões e concepções ocultadas pela colonialidade. Na atual conjuntura, com avanços de visões conservadoras em que o respeito à diferença torna-se cada vez mais comprometido, é fundamental defender a escola como palco do diálogo e da integração de todos.

No Mapuá, por meio da prática religiosa valendo-se dos artefatos sagrados cotidianamente - as pessoas simbolizam realidades virtuais, materiais e espirituais que contribuem para a manutenção e a integração da vida em sociedade. São mecanismos que permitem reafirmar a estrutura interna de cada família e comunidade na relação com o natural e o sobrenatural. O aspecto religioso é assim - indispensável para se entender a estrutura social e, nesse movimento, valores, simbologias, cosmologias, práticas que sustentam a vida em sociedade. 
De acordo com Danner, Bavaresco e Danner,

[...] o mundo é religioso, profundamente religioso, dependente de modo fundamental seja do suporte das grandes religiões, seja das bases essencialistas e naturalizadas desde elas emanadas para sua motivação diária, como substrato para sua vida cotidiana e como base de seus valores e de suas práticas. Negar isso seria negar o óbvio ululante; ignorar isso seria inviabilizar o próprio universalismo em termos de fundamento, conteúdo e motivação. (DANNER; BABARESCO; DANNER, 2019, p. 445).

Negar a importância da religiosidade para a formação escolar do sujeito é negar a própria escola como ferramenta de promoção de sociabilidade. Daí entender que o currículo, como elemento-chave da formação, carece de ser não apenas flexível, mas dialógico, dinâmico e plural. Um currículo que aproxime a escola da realidade, experiências e vivências dos alunos de modo a promover uma formação integral, defendida por diferentes estudiosos e, até pela BNCC.

Como mostrado no texto no Mapuá/Marajó, a religião é linguagem, expressão, código e performance de vida que envolvem produção e ressignificação de saberes e poderes locais, traduzidos e refletidos nos rituais em sintonia com a logística geográfica do rio e da floresta. Por meio dessa linguagem, os ribeirinhos ressignificam cosmologias e cosmovisões locais; essas - por sua vez - orientam e ajudam a forjar a identidade cultural de cada comunidade e indivíduos. Daí concluir que a religiosidade é elemento, ferramenta, aspecto constituinte da cultura escolar.

\section{REFERÊNCIAS}

ANTUNES- ROCHA. M. I; DINIZ, L. de S.; OLIVEIRA, A. M. Percurso Formativo da Turma Dom José Mauro: segunda turma do curso de Licenciatura Plena em Educação do Campo da FAE-UFMG. In: MOLINA, M. C.; SÁ, L. M. (org.). Licenciaturas em educação do campo: registros e reflexões a partir das experiências-piloto (UFMG; UnB; UFBA e UFS). Belo Horizonte: Autêntica Editora, 2011.

ARROYO, M. G. A educação básica e o movimento social do campo. In: FERNANDES, B. M. (Org.). A educação básica e o movimento social do campo. Brasília, DF: Articulação Nacional Por Uma Educação Básica do Campo, 1999. 
ARROYO, M. G. Currículo, território em disputa. 2. ed. Petrópolis, RJ: Vozes, 2011.

BONI, P. C.; MORESCHI, B. M. Fotoetnografia: a importância da fotografia para o resgate etnográfico. Doc On-line, n. 3, p.137-157, 2007. Disponível em: www.doc.ubi.pt. Acesso em: 20 set.2015.

BRASIL. MEC. Base Nacional Comum Curricular para Educação Infantil e Ensino Fundamental. 2017. Disponível em: basenacionalcomum.mec.gov.br/wpcontent/uploads/2018/o2/bncc-20dez-site.pdf. Acesso em: 20 out. 2018.

BRASIL. MEC. Lei de Diretrizes de Bases da Educação Nacional, Lei Nº 9.394/1996. Disponível em: https://www.cpt.com.br/ldb/lei-de-diretrizes-e-bases-da-educacao-completainterativa-e-atualizada. Acesso em: 13 jan. 2019.

BRASIL. Parâmetros Curriculares Nacionais do Ensino Religioso, 2009. Disponível em: http://www.portcom.intercom.org.br/pdfs/fcd5be4b5d7d8e84a850ee93a46ao4ob.pdf. Acesso em: 10 jan. 2019.

CARNEIRO, M. A. LDB fácil: leitura crítico-compreensiva, artigo a artigo. 24. ed. Petrópolis, RJ: Vozes, 2018.

COSTA, E. M. Memórias em escavações: narrativas de moradores do rio Mapuá sobre os modos de vida, cultura material e preservação do patrimônio arqueológico (Marajó, PA, Brasil). 2018. Tese (Doutorado) - Programa de Pós-graduação em Antropologia (PPGA), Universidade Federal do Pará, Belém, 2018.

DANNER, L.F.; BAVARESCO, A.; DANNER, F. Universalismo entre religiões e modernidade: a fundamentação do universalismo epistemológico-moral por meio da cooperação entre razão e religião. Horizonte, v. 17, n. 52, p. 436-461, jan./abr. 2019. Disponível em:

http://periodicos.pucminas.br/index.php/horizonte/issue/view/1091. Acesso em: 20 out. 2019.

DELGADO, L. de A. N. A história oral: memória, tempo, identidades. 2. ed. Belo Horizonte: Autêntica, 2010.

FAGUNDES, R. S. A função da retórica política de Antônio Vieira na Restauração: uma análise do sermão de Santo Antônio. Religare: revista do Programa de Pós-graduação em Ciências das Religiões da UFPB, v. 15, n. 1, p. 324-350, 2018. Disponível em: www.periodicos.ufpb.br. Acesso em: 12 jan. 2019.

FREIRE, P. Pedagogia do oprimido. 46. ed. São Paulo: Paz e Terra S/A, 2007.

GALVÃO, E. Santos e visagens: um estudo da vida religiosa de Itá, Amazonas. São Paulo: Cia. Editora Nacional, 1955.

GEERTZ, C. O saber local: novos ensaios em antropologia interpretativa. Petrópolis: Vozes, 1997.

GEERTZ, C. Uma descrição densa: por uma teoria interpretativa da cultura. In: GEERTZ, C. A interpretação das culturas. Rio de Janeiro: Guanabara-Koogan, 2012. 
IBGE. Cidades. 2010. Disponível em: https://cidades.ibge.gov.br/brasil/pa/breves/panorama. Acesso em: 10 jan. 2019.

MAUÉS, R. H. Um aspecto da diversidade cultural do caboclo amazônico: a religião. Estudos avançados, São Paulo, v. 19, n. 53, p. 259-274, 2005.

PIANA, M. C. As políticas educacionais: dos princípios de organização à proposta de democratização. In: A construção do perfil do assistente social no cenário educacional [online]. São Paulo: Editora UNESP: Cultura Acadêmica, 2009. Disponível em: http://books.scielo.org. Acesso em: 2 jan. 2019.

SALLES, W.F. Paul Ricouer e a lógica do perdão. Horizonte, v. 17, n. 52, p. 414-435, jan./abr. 2019. Disponível em: http://periodicos.pucminas.br/index.php/horizonte/issue/view/1091. Acesso em: 20 out. 2019.

SANTOS, M. A. R. dos; SOARES, F. A. P. O ensino religioso e as políticas públicas educacionais: enfoques na contemporaneidade. Religare: revista do Programa de Pósgraduação em Ciências das Religiões da UFPB, v. 15, n. 1, p. 75-96, 2018. Disponível em: www.periodicos.ufpb.br. Acesso em: 12 jan. 2019.

SANTOS, R. O. dos; JUNQUEIRA, S. R. A. Ciência da religião aplicada no currículo do ensino religioso do estado do Pará. Religare: revista do Programa de Pós-graduação em Ciências das Religiões da UFPB, v. 15, n. 1, p. 97-126, 2018. Disponível em: www.periodicos.ufpb.br. Acesso em: 12 jan. 2019.

SARRAF-PACHECO, A. En el corazón de la Amazonia: identidade, saberes e religiosidade no regime das águas. 2009, 350f. Tese (Doutorado em História Social). Programa de Pósgraduação em História Social, Pontifícia Católica de São Paulo, São Paulo, 2009. Disponível em: https://sapientia.pucsp.br/bitstream/handle/13141/1/Agenor\%20Sarraf\%20Pacheco.pdf. Acesso em: 11 jun. 2015.

SCHAAN, D. P. Marajó: arqueologia, iconografia, história e patrimônio. Erechim, RS: Habilis, 2009.

SHIGUNOV NETO, A.; MACIEL, L. S. B. O ensino jesuítico no período colonial brasileiro: algumas discussões. Educar, Curitiba, n. 31, p. 169-189, 2008.

SILVA, T. T. da. Documentos de identidade: uma introdução às teorias do currículo. 2. ed. Belo Horizonte: Autêntica, 2007.

VALENTE, G. A. A religiosidade na prática docente. Revista Brasileira de Estudos Pedagógicos, Brasília, v. 98, n. 248, p. 198-211, jan./abr. 2017. Disponível em: http://www.scielo.br/scielo.php?pid=S217666812017000100198\&script=sci_abstract\&tlng=pt. Acesso em: 15 nov. 2018.

WAGLEY, C. Uma comunidade amazônica: estudo do homem nos trópicos. 3. ed. Belo Horizonte: Itatiaia: São Paulo: Editora da Universidade de São Paulo, 1988. 